\title{
ArcheoSciences
}

Revue d'archéométrie

33 (suppl.) | 2009

Mémoire du sol, espace des hommes

\section{Archaeological interpretation of combined magnetic and GPR surveys of the roman town Flavia Solva, Austria}

Wolfgang Neubauer, S. Seren, Alois Hinterleitner, Klaus Löcker and P. Melichar

\section{(2) OpenEdition}

\section{Journals}

Electronic version

URL: https://journals.openedition.org/archeosciences/1613

DOI: 10.4000/archeosciences.1613

ISBN: 978-2-7535-1599-4

ISSN: $2104-3728$

Publisher

Presses universitaires de Rennes

\section{Printed version}

Date of publication: 30 October 2009

Number of pages: $225-228$

ISBN: 978-2-7535-0943-6

ISSN: $1960-1360$

\section{Electronic reference}

Wolfgang Neubauer, S. Seren, Alois Hinterleitner, Klaus Löcker and P. Melichar, "Archaeological interpretation of combined magnetic and GPR surveys of the roman town Flavia Solva, Austria", ArcheoSciences [Online], 33 (suppl.) | 2009, Online since 30 October 2011, connection on 01 February 2022. URL: http://journals.openedition.org/archeosciences/1613; DOI: https://doi.org/10.4000/ archeosciences.1613 


\title{
Archaeological interpretation of combined magne- tic and GPR surveys of the roman town Flavia Solva, Austria
}

\author{
W. Neubauer*, S. Seren **, A. Hinterleitner **, \\ K. LÖCKer ** and P. Melichar **
}

Key words: Magnetics, GPR, Archaeological interpretation, Roman town.

\section{The Roman Town Flavia Solva}

The Roman town Flavia Solva in the Roman province Noricum (Styria, Austria) shows a rectangular street system known from aerial archaeology and excavations. Flavia Solva was founded in the early 1 st century AD as a dwelling of local Late Iron Age people in the Roman province of Noricum. It already got the status of a Roman municpium around $70 \mathrm{AD}$ under the Emperor Titus Flavius Vespasianus (69-79 AD). The name of the town and its location are known since the 19th century by excavations and surface finds - the main excavation activity dates to the $20^{\text {th }}$ century. These excavations lacked modern standards - the outlines of most of the buildings were found by simply following the outer walls near the surface - and uncovered only small parts of the municipal area but nonetheless provided the knowledge of the approximate extent of the town with 41 insulae and a rectangular street system. Flavia Solva appears to have been destroyed during the Marcomanni Wars in the late $2^{\text {nd }}$ century $\mathrm{AD}$. The end of the settlement activities seems to be datable to the beginning of the 5th century $\mathrm{AD}$. The municipal area of the ancient town is located at the western bank of the river Mur and shows an extent of some 39 ha, partially destroyed by the modern town, roads and industrial zones.

\section{Systematic Prospecting}

Initial resistivity surveys in 1998 located the forum of the town searched for in vain for over 125 years (Groh et al., 1999). This data showed high resistance contrasts that indicated outstanding GPR results for the prospecting of further details of the town structure. During the last ten years the team Archeo Prospections ${ }^{\oplus}$ carried out systematic geophysical prospection combining magnetic and GPR surveys to explore the extent and inner structure of the Roman town. So far an area of $54.300 \mathrm{~m}^{2}$ has been surveyed with GPR (Fig. 1) and an area of $138.400 \mathrm{~m}^{2}$ with magnetometry (Fig. 2). The early GPR surveys from the year 2000 have been repeated with latest instrumentation and higher spatial resolution $(0.25 \times 0.05 \mathrm{~m})$ and document the progress in the archaeological application of GPR (Neubauer, 2008).

\footnotetext{
*Vienna Institute for Archaeological Science, University of Vienna, Franz Klein-Gasse 1/V, A-1190 Vienna, Austria. (Wolfgang.Neubauer@univie. ac.at)

** Central Institute for Meteorology and Geodynamics, Hohe Warte 38, A-1190 Vienna, Austria.
} 

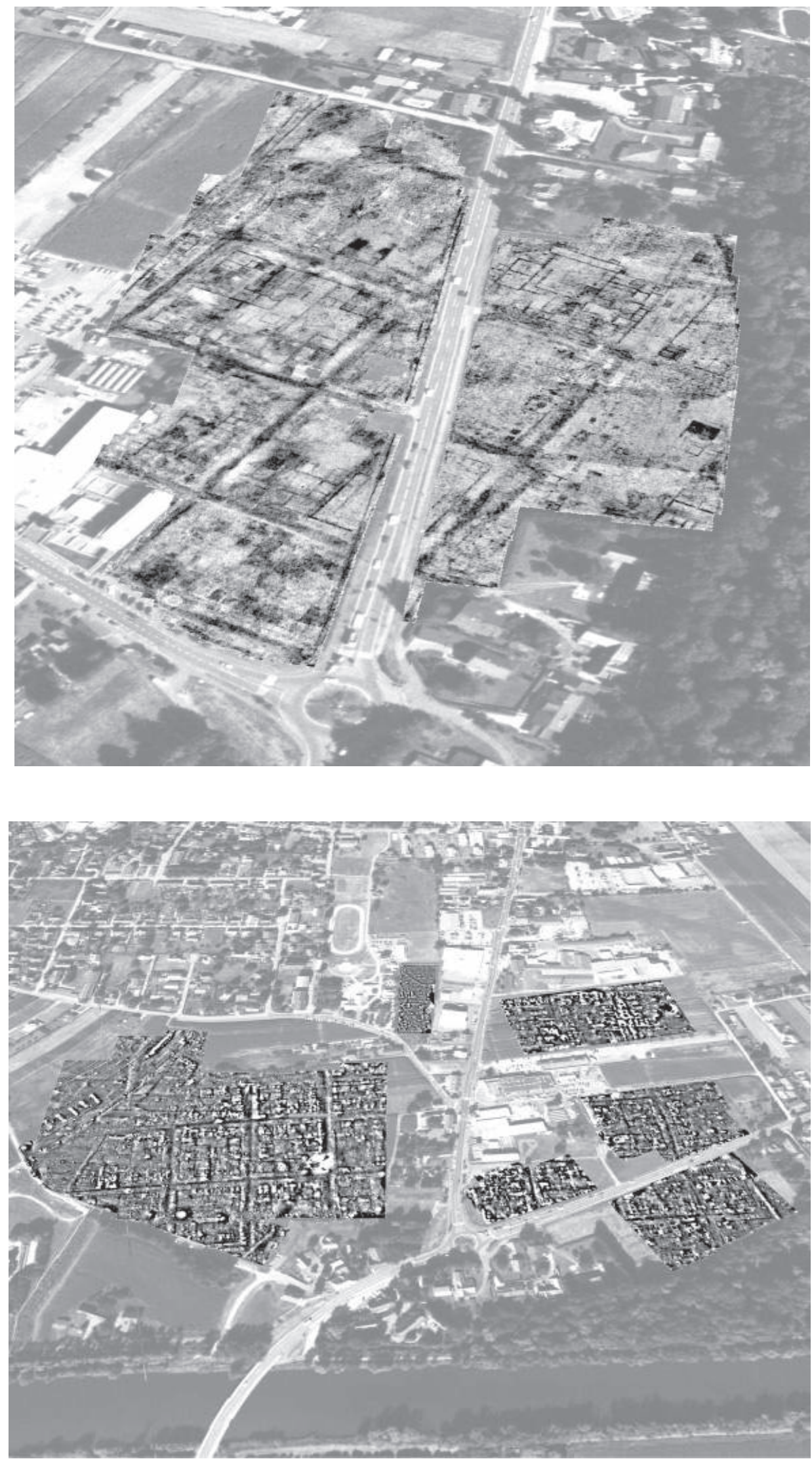

Figure 1: The GPR depth slice (0.90$1.60 \mathrm{~m}$ ) of an area of $54.300 \mathrm{~m} 2$ of the north-east part of the roman town Flavia Solva carried out by Archeo Prospections ${ }^{\bullet}$ overlays the aerial photo of the modern town Wagna. Ortho Photo: GIS Steiermark.
Figure 2: The visualisation of the magnetic prospection of the roman town Flavia Solva overlays the aerial photo of the modern town Wagna. In total $138.400 \mathrm{~m} 2$ were prospected by Archeo Prospections ${ }^{\circ}$ using a multisensor caesium-gradiometer. Ortho Photo: GIS Steiermark. 


\section{THE LARGE SCALE GPR SURVEYS}

The authors started in 1998 with large area GPR surveys covering normally 1 to 10 ha per archaeological site. Therefore it was necessary to develop enhanced GPR systems for intensive field survey and appropriate logistics, as well as fast and reliable processing software. The developed software module ApRadar, first released in 1999 and continuously refined over the years, made it possible to visualize even large area surveys already in the field. This was of high importance for data quality control as well as for the planning of the ongoing large area surveys. The fast data processing is mainly based on the production of $3 \mathrm{D}$ data arrays based on densely measured grids. Such dense grids $(\leq 0.05 \times 0.5 \mathrm{~m})$ are required to resolve the archaeological structures as for example the Roman walls at Flavia Solva are normally $0.4-0.6 \mathrm{~m}$ wide. The data forming the $3 \mathrm{D}$ data array is derived from the initial data stream e.g. by summarizing the amplitudes of the reflected electromagnetic signal using a defined voxel size according to the wavelength and the velocity. Using the velocity model defined by CMP-measurements the data is converted into depth information. This makes it possible to derive horizontal depth slice maps. This includes multifacet slicing and animated fly-through as first presented by Archeo Prospections ${ }^{\circledR}$ in 1998 to the archaeological prospecting community.

The multidirectional animation of the slices introduced a new way of explorative data analysis for the enhanced archaeological interpretation of GPR data. Many sloping structures as stairways, canals or subtle spatial relationships within the data are revealed by the animated data-sets. From 2000 on GPR surveys have been carried out in Flavia Solva (Neubauer $e t a l$., 2001). The primary objective of the prospection work was a detailed survey of the northeastern part of the municipal area. During this first prospection project an area of over 4 ha has been recorded three-dimensionally in detail in 10 days work. The survey has then been carried out using a PulseEKKO 1000 GPR system with 450 and $900 \mathrm{MHz}$ antennas in a raster of $0.5 \times 0.05 \mathrm{~m}$, covering the greater parts of 10 insulae.

\section{Magnetic SURVeYS}

For a first comparison with the GPR results an area of $15000 \mathrm{~m}^{2}$ situated east of a modern main road investigating four insulae was magnetically prospected in 2000 using a 5 -sensor caesium-gradiometer in a raster of $0.5 \times 0.125 \mathrm{~m}$. Most of the walls visible in the GPR timeslices are as well visible in the magnetics appearing as negative anomalies.
Surprisingly the insulae which did not show any wall structures in the GPR showed buildings as positive anomalies. Nearby excavations could provide an explanation. The positive anomalies in the magnetics could be due to brick walls. As the GPR was carried out in the wet season the bricks should have been water saturated embedded in wet clayey and sandy sediments. Therefore the brick wall did not produce a respective signal in the GPR survey. Following this first campaign the southern part of the town was completely surveyed as well as the still open areas in the vicinity of the modern industrial zone.

\section{ArChaEOlogical inTERPRETATION}

In close collaboration with the interpreting archaeologists improved image processing techniques and visualization methods have been developed, which makes it possible to represent the archaeologically relevant information at its best. Only fully trained and skilled archaeologists with special knowledge of the geophysical prospection methods and sufficient excavation experience are able to decipher all archaeologically relevant information out of the huge data volume and to redraw this information into an archaeological interpretation map of the site. Without this archaeological interpretation we consider geophysical data to be worthless in terms of archaeology. The combination of all prospection data for the subsequent detailed archaeological interpretation is done in a GIS (Fig. 3).

The horizontal depth slices show the rectangular street system dividing the town in various insulae. As in most insulae a plenty of wall structures from monumental public buildings as well as private dwellings became obvious. On basis of these first GPR surveys an archaeological and historical interpretation of the northeastern part of the municipal area has been worked out including excavation data (Groh et al., 2002). With this work it was for the first time possible to show the astounding results of profound archaeological interpretation of professionally collected prospection data.

A big open square bordered by halls which has been located by earlier resistivity surveys in the eastern part of insula XXVI could be confirmed as the forum of the municipium. In the area adjoining to the west we were able to explore a representative residential house in detail. This quadratic peristyle villa features an area of about $900 \mathrm{~m}^{2}$ and includes an ample garden to the north. This building also shows a direct entrance to the halls of the forum.

Parts of the forum are situated under a heavily frequented modern road and could not be prospected. East of the road the basilica belonging to the forum has been located and fur- 


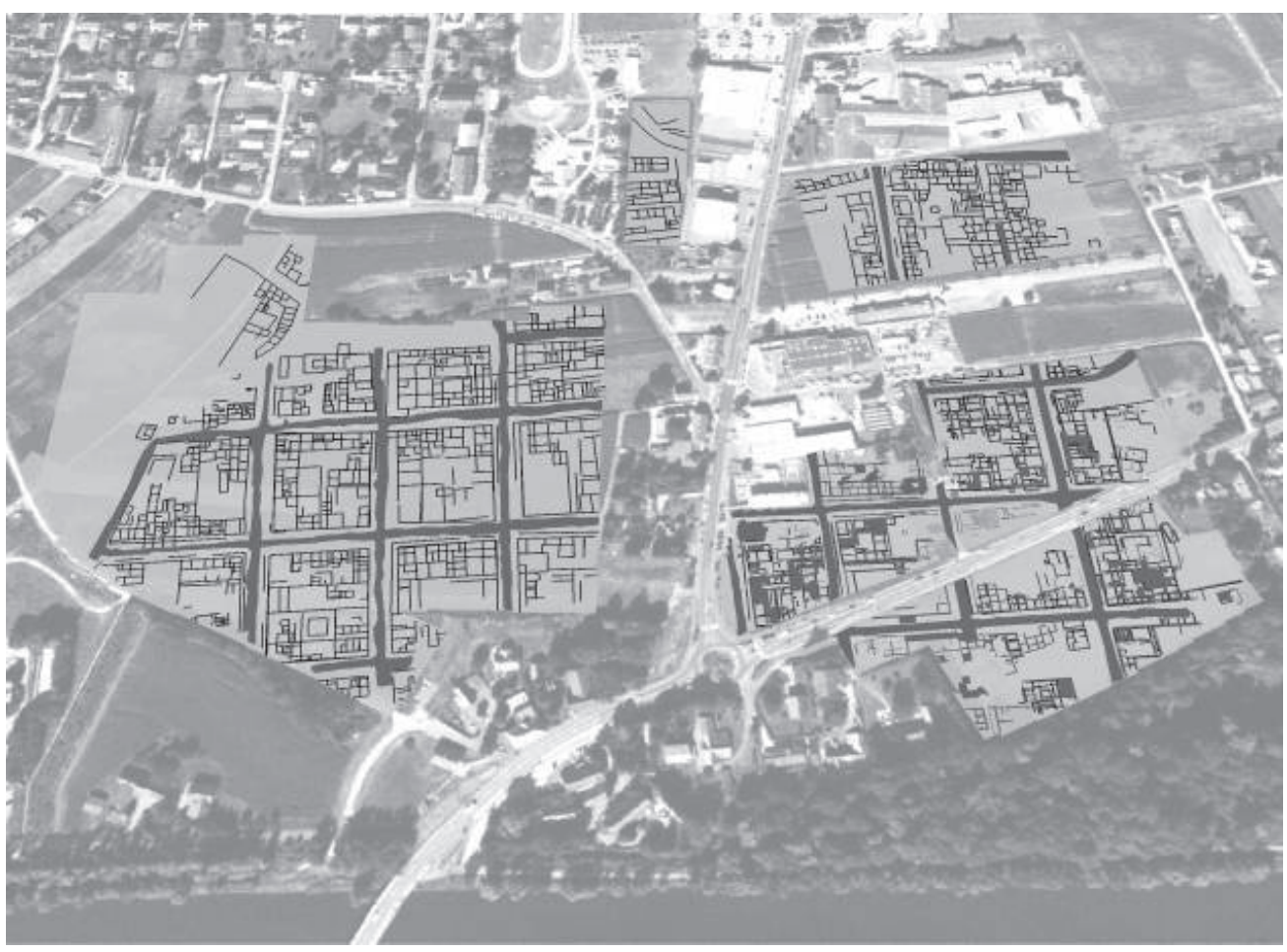

Figure 3: Archaeological Interpretation map of the bombined interpretation of the magnetic ang GPR Prospection overlays the aerial photo of the modern town Wagna.. Ortho Photo: GIS Steiermark. ther to the east some large halls which could have been used as storehouses connected to a possible port at the Mur river. In the northeastern part of the municipal area a downright huge villa urbana with a central peristyle court including water basins has been found. Out of the combined interpretation with the magnetic survey data former rooms with hypocausts could be distinguished with high probability.

\section{References}

Groh, St., Neubauer, W. and Eder-Hinterleitner, A., 1999. A resistivity survey to locate the forum of the Roman town Flavia Solva. In: Faßbinder, J., Irlinger, W. (eds.). Archaeological Prospection, Arbeitshefte des Bayerischen Landesamtes für Denkmalpflege 108: 38-39.
Groh, St., Neubauer, W., Seren, S., Eder-Hinterleitner, A. and LöCKER, K., 2002. Geophysikalische Messungen im nordöstlichen Stadtteil von Flavia Solva: Interpretation und archäologisch-historische Auswertung. Sonderschriften des ÖAI, 71: 2002, 79-132.

Neubauer, W., Eder-Hinterleitner, A., Seren, S. and Melichar, P., 2001. Combined high resolution magnetics and GPR surveys of the Roman town Flavia Solva (Austria). In: Doneus et al., Archaeological Prospection, 4th int. conference Vienna, 154-156.

Neubauer, W., 2008. Der Blick in die Tiefe - Die geophysikalische Erkundung des Stadtgebiets von Flavia Solva. Schild von Steier, Archäologische und numismatische Beiträge aus dem Landesmuseum Joanneum 21: 293-316. 